\title{
Conversion of Polymer and Resin Wastes into the Valuable Products
}

Roman M Kenzhin, Yury I Bauman, Ilya V Mishakov, Inna V Zibareva and Aleksey A Vedyagin*

Boreskov Institute of catalysis SB RAS,Russian Federation

Submitted: December 28, 2018; Published: January 08, 2019

*Corresponding author: Aleksey A Vedyagin, Boreskov Institute of Catalysis SB RAS, Russian Federation

\begin{abstract}
Progress in materials science, which took place more than a century ago, has change the life of mankind cardinally. Starting from the moment of their invention, plastics and a variety of materials made from them have filled up almost all areas of the industrial and household activities. The dark side of the picture is that the plastics wastes being hardly self-degraded constitute a menace to the environmental and the health of all living forms. Nowadays, the most part of the plastic wastes are disposal in landfills. Development of new efficient approaches to conversion of such wastes into the valuable products is of great importance. The present research is devoted to analysis of possibility of the polymer and resin wastes processing into nanostructured carbon materials in a closed reaction volume.
\end{abstract}

Keywords: Plastic wastes; Polymers; Resins; Disposal; Incineration; Recycling

\section{World of Plastics}

The first man-made plastic material was invented in England by Alexander Parkes in 1856 [1]. Almost 80 years after the invention, in 1940s, mass production of the plastics has begun along with the improvements in chemical technology taking place after World War I. Since 1964, the production volume has increased twenty-fold and exceeded 300 million tonnes in 2011 (Figure 1), and in the coming 30 years, it is expected to treble [2]. Plastic materials possess a combination of low cost and unique properties that makes them to be of great popularity and wide usage $[3,4]$. No doubt that today it is completely impossible to envisage the modern world without plastics.

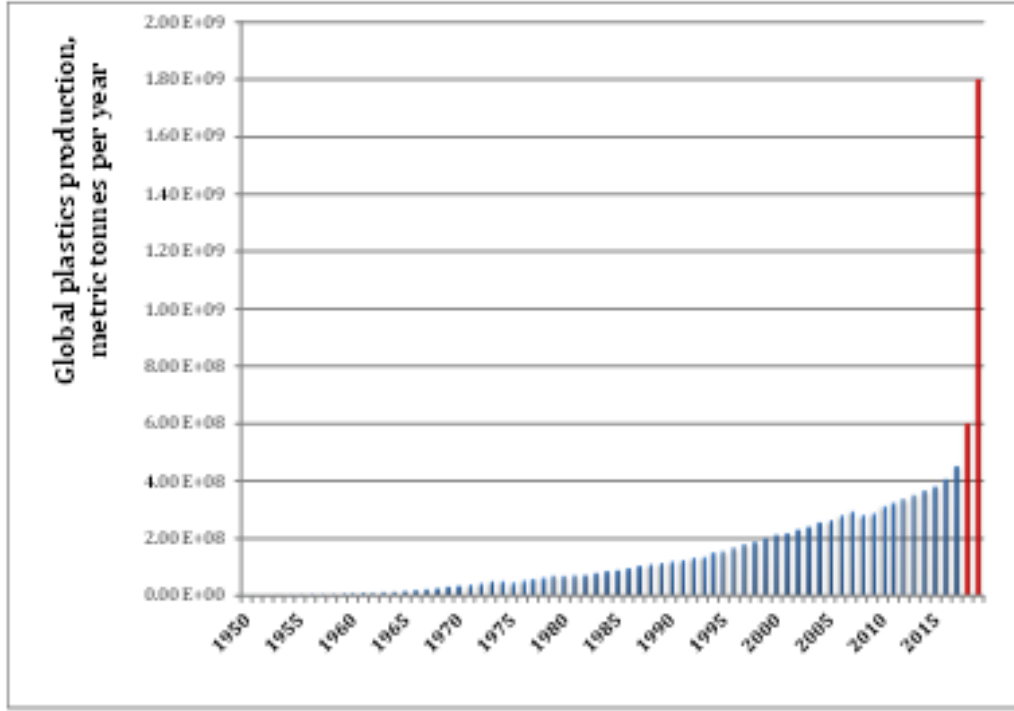

Figure 1: Global plastics production for 1950-2017 and projected levels of production for 2025 and 2050. 
Table 1: Main types of plastic resins.

\begin{tabular}{|c|c|c|c|}
\hline No & Polymer (resin) & Abbreviation & Areas of application \\
\hline 1 & $\begin{array}{l}\text { Polyethylene } \\
\text { terephthalate }\end{array}$ & PET & $\begin{array}{l}\text { Water and soft drink bottles, salad domes, biscuit trays, salad dressing and peanut butter containers, } \\
\text { carriers for magnetic tape and backing for pressure-sensitive adhesive tapes }\end{array}$ \\
\hline 2 & $\begin{array}{l}\text { High density } \\
\text { polyethylene }\end{array}$ & HDPE & $\begin{array}{l}\text { Milk bottles, freezer bags, dip tubs, crinkly shopping bags, ice cream containers, juice bottles, } \\
\text { shampoo, chemical and detergent bottles, bottle caps, coax cable inner insulator, banners, boats, } \\
\text { ballistic plates, fuel tanks for vehicles, swimming pool installation, backpacking frames, corrosion } \\
\text { protection for steel pipelines, electrical and plumbing boxes, far-IR lenses, folding chairs and tables, } \\
\text { microwave telescope windows, chemical-resistant piping, natural gas distribution pipe systems, } \\
\text { water pipes for domestic water supply and agricultural processes }\end{array}$ \\
\hline 3 & $\begin{array}{l}\text { Low density } \\
\text { polyethylene }\end{array}$ & LDPE & $\begin{array}{l}\text { Cosmetic containers, commercial cling wrap, corrosion-resistant work surfaces, packaging for } \\
\text { computer hardware and optical disc drives, playground slides }\end{array}$ \\
\hline 4 & Polyvinyl chloride & PVC & $\begin{array}{l}\text { Squeeze bottles, cling wrap, shrink wrap, rubbish bags, urine containers, blood containers, blood } \\
\text { taking and blood giving sets, catheters, heart-lung bypass sets, hemodialysis sets, commercial } \\
\text { signage products, flooring, pipes for municipal and industrial applications, insulation on electrical } \\
\text { cables, skiing equipment, shoes, jackets, aprons, and sports bags, wire rope and aircraft cable }\end{array}$ \\
\hline 5 & Polypropylene & PP & $\begin{array}{l}\text { Microwave dishes, ice cream tubs, potato chip bags, dip tubs, piping systems, insulation for electrical } \\
\text { cables, nonwoven diapers and sanitary products, filters for air, gas, and liquids, cold-weather base } \\
\text { layers, warm-weather clothing, carpets, rugs and mats }\end{array}$ \\
\hline 6 & Polystyrene & PS & $\begin{array}{l}\text { CD cases, water station cups, plastic cutlery and dinnerware, imitation 'crystal glassware', video } \\
\text { cases, smoke detector housings, license plate frames, plastic model assembly kits, Petri dishes, } \\
\text { laboratory containers (test tubes and microplates), film capacitors, thermal insulators }\end{array}$ \\
\hline 7 & $\begin{array}{l}\text { Expanded } \\
\text { polystyrene }\end{array}$ & EPS & $\begin{array}{l}\text { Foamed polystyrene hot drink cups, hamburger take-away clamshells, foamed meat trays, protective } \\
\text { packaging for fragile items, molded sheets for building insulation, solid blocks }\end{array}$ \\
\hline
\end{tabular}

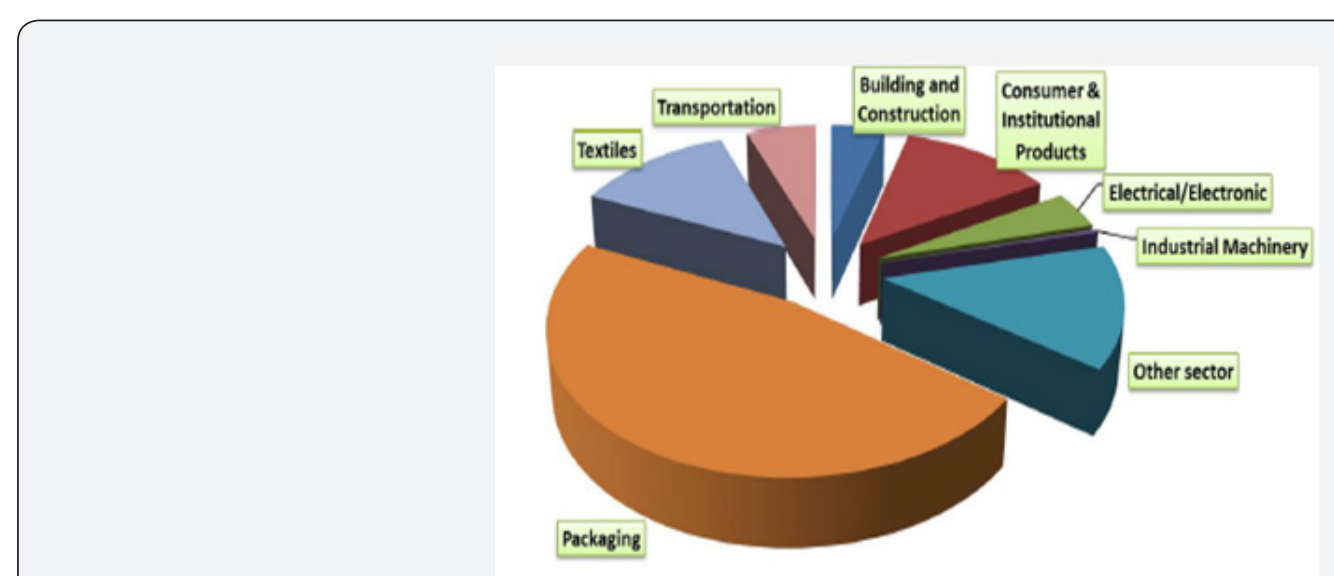

Figure 2: Share of global plastic waste generation by industrial sector.

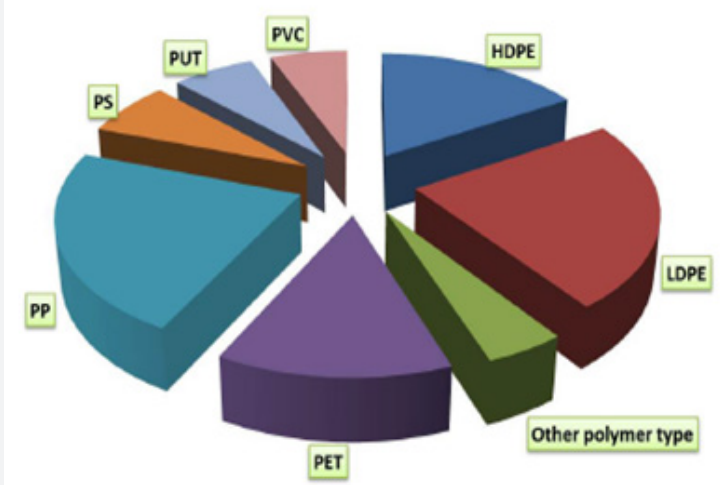

Figure 3: Share of global plastic waste generation by type of plastics. 
Plastic materials penetrated mankind's everyday life, and everyone is being in the contact with them every day. The main types of plastic resins and areas of their application are summarized in (Table 1). As it follows from Table 1 and (Figure 2), almost a half of produced plastics are used for packaging purposes. As packaging materials, they are especially inexpensive, lightweight and high performing. Other benefits of their usage are that low weight of plastic packaging materials reduces fuel consumption in transportation, and its barrier properties keep food fresh longer, reducing food waste. All these result in the replacing of other packaging materials by plastics. In terms of plastic type, polyethylene terephthalate, polyethylene (high and low density), and polypropylene are mostly applied (Figure 3). Besides the packaging, the last two types play a major role in various piping systems. At the same time, chlorinated polymers (for instance, polyvinylchloride), due to their specific application areas such as medicine (blood containers, blood taking and blood giving sets, catheters, heart-lung bypass sets, hemodialysis sets), building (flooring, pipes for municipal and industrial applications, insulation on electrical cables) and sport (skiing equipment, shoes, jackets, aprons, sports bags), are also of great importance. It should be noted that production of polyvinylchloride is considered nowadays as an important part of the world chlorine industry [5-7].

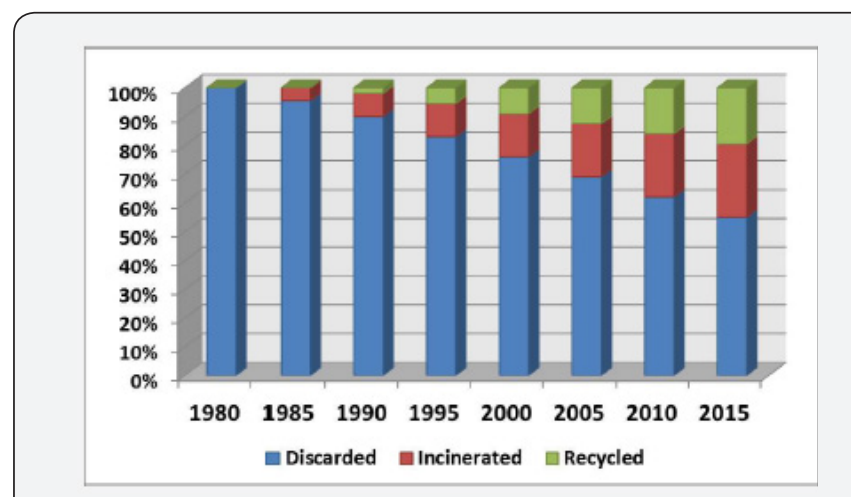

Figure 4: Estimated share of global plastic waste by disposal method.

Despite the attractiveness of the plastics, there are two negative environmental aspects that should be emphasized. First of all, a question of toxicity of such materials is still under open discussion [8-10]. This problem is connected with the facts that polymeric items can contain molecules of unreacted monomers or some additives used to improve both the physical properties of the plastics and their usability. All these components can be slowly extracted from the items and affect the health of the users. Moreover, the polymers are stable only within relatively narrow temperature range, and, thus, they can undergo decomposition being under the action of thermal or physical stress. It results in additional emission of harmful and hazardous contaminants. In the case of halogen-substituted plastics, this situation becomes even more deteriorated [9]. The second "dark side" of the coin deals with growing "mountains" and "oceans" of plastic wastes. As it is evident from Figure 4, until 1980 almost
$100 \%$ of plastic wastes were discarded. Nowadays, the portion of discarded wastes does not exceed $60 \%$. Taking into account global production values (Figure 4), it can be estimated that the absolute value of throwaway plastics was doubled during the last 35 years.

\section{Global Plastic Waste Management}

In general, utilization of plastic wastes proceeds via one of five main directions shown in (Figure 5) [11-16]. As it was already mentioned, disposal in landfills remains the biggest in volume direction facing the global environmental problem [11]. Then follow incineration, recycling, degradation and composing. Incineration (combustion) process was the first approach for plastics processing [17-19]. In this case, plastics are considered as a solid burnable fuel, and used mostly for heat recovery. It gives the second name for this direction - waste-toenergy. However, depending on the type of plastic, combustion of wastes leads to formation of huge amount of toxic substances $[17,20,21]$. First of all, it concerns polyvinylchloride and other halogen-substituted polymers. Thereby, from ecological point of view, incineration of such materials should be prohibited. The next direction of the plastic waste disposal, which is under the intensive developing, is recycling [16,21-32]. Depending on the type of exposure, the process can be divided on mechanical and chemical recycling [32]. Chemical recycling, in its turn, combines such sub-processes as chemolysis, pyrolysis, fluid catalytic cracking, hydrogen techniques and gasification. In some cases, the recycling process can be merged with processing of biomass and renewables [27,31]. In general, the present direction is aimed to have at the end of the line production of gaseous and liquid fuels $[18,19,21,29,30]$.

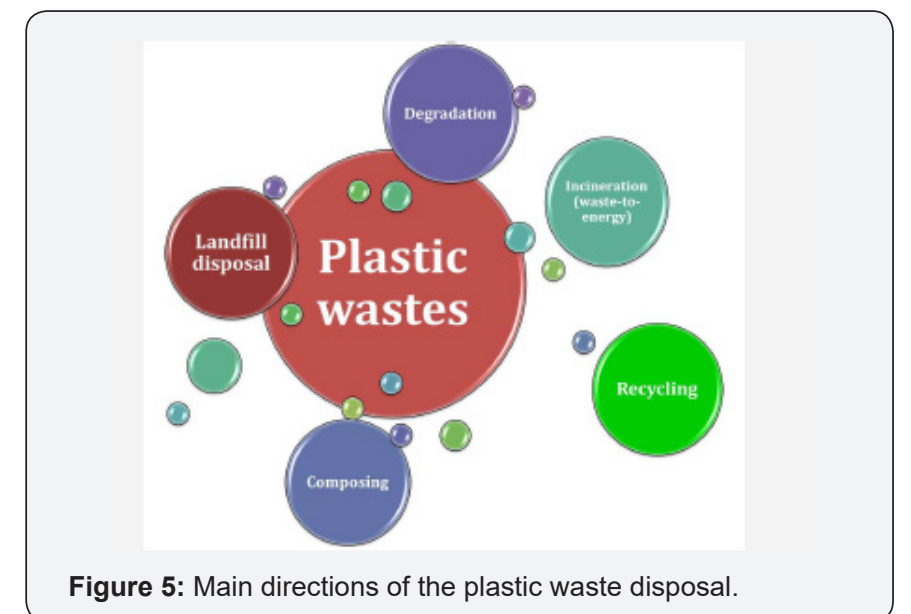

Degradation and composing are the particular cases of the polymer recycling technologies. Within the composing approach, spent plastic items are considered as additives or fillers for various building and composite materials [25]. Degradation can be abiotic or biological [33]. A concern of efficient biodegradation of non-degradable synthetic polymers using microorganisms and enzymes attracts a growing interest [20,34-39]. Additionally, a new class of bioplastics with shortened biodegradation period 
becomes more and more popular, especially for the packaging application [40-43]. Another example of easy degradable polymers is plastics with photocatalysts embedded into polymer matrix $[44,45]$. Such composite materials could be degraded effectively in ambient air under sunlight exposure. Among the photocatalysts used, titania, zinc oxide, $\alpha-\mathrm{FeOOH}$ and $\mathrm{H}_{3} \mathrm{PW}_{12} \mathrm{O}_{40}$ are the most studied. Kinetics of polymer degradation can be improved by combining the process with chemical exposure. Regarding with it, such processes as hydrolysis, acidolysis, alcoholysis, aminolysis, alcoholysis and glycolysis should be mentioned [46]. Application of supercritical fluids is also reported to contribute to the recycling process efficiency [4749]. Taking into account all mentioned above, the plastic wastes recycling concept can be schematically presented as shown in Figure 6. Spent plastic items (bottles, containers, bags, pipes, etc.) after the appropriate classification could be recycled into fuel, chemicals, new carbonaceous or composite materials, or incinerated with energy recovery.

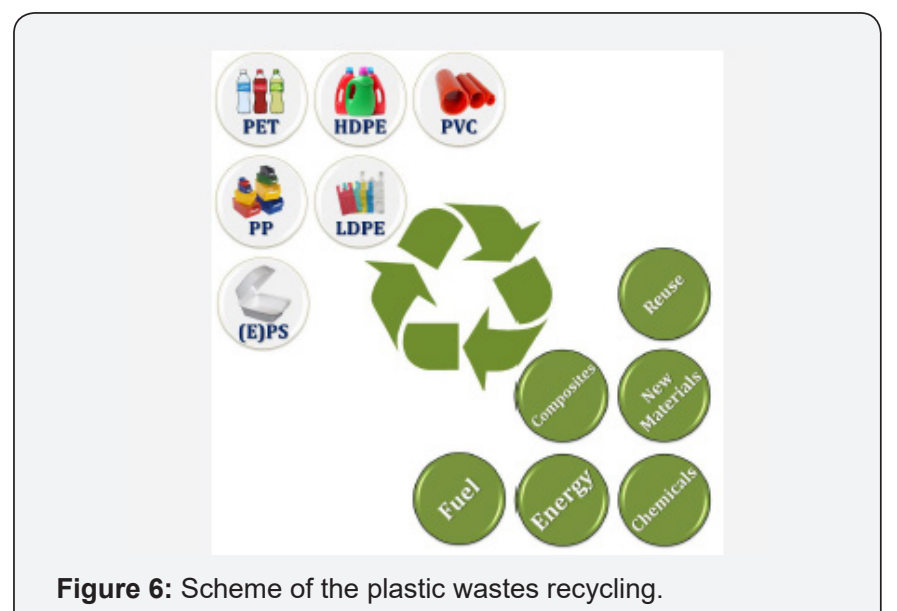

\section{Nanostructured Carbon Derived from Plastic Wastes}

Transformation of polymers into carbon materials is a welldeveloped process. It underlies the industrial technology for production of carbon fibers via pyrolysis of polyacrylonitrile $[50,51]$. The temperatures of this process quite often exceed $1000{ }^{\circ} \mathrm{C}$. On the other hand, Prof. Gedanken and co-workers have reported recently in their numerous research papers the efficiency of relatively new approach called reaction under autogenic pressure at elevated temperatures (RAPET) [52-55]. Reactions within this concept are performed in a closed reaction volume. As a result, various nanostructured materials (metal oxides; carbides of silicon, tungsten, and molybdenum; carbons) of unique morphology and properties can be produced. It should be noted that this approach is applicable for the fabrication of carbon-related materials via decomposition of organic precursors [52,54]. In our recent publications it was shown that decomposition of various organic precursors can be successfully performed in a closed reaction volume in the presence of bulk nickel-containing alloys [56-60]. In this case, presence of halogen atoms in the precursor's molecule is strictly necessary to realize the mechanism of metal dusting - self-disintegration of bulk metals under the action of aggressive reaction media [61-63]. If molecule of organic precursor contains some other heteroatoms (for example, nitrogen) then the carbon nanostructures being formed will be doped with these heteroatoms [57].

Up to now, the RAPET approach was applied for recycling of polymer and resin wastes to nanostructured carbon. Similarly, to the recent studies, the RAPET experiments were performed in a quartz ampoule $(\mathrm{d}=4-5 \mathrm{~mm}, \mathrm{~V} \sim 0.2 \mathrm{ml})$ used as a reactor. A piece of nichrome wire (commercial $\mathrm{Ni}-\mathrm{Cr}$ alloy consisting of $80 \mathrm{wt} . \% \mathrm{Ni}$ and $20 \mathrm{wt} . \% \mathrm{Cr} ; 0.2-0.3 \mathrm{mg}$ ) was placed in the ampoule together with 2-3 mg of polymer (polyethylene, polytetrafluorethylene, polyvinylchloride) or resin waste. The ampoule with reaction mixture was sealed and brought to thermal treatment at certain temperature for $2 \mathrm{~h}$. After the reaction procedure, the ampoule was carefully opened, and the contents were studied by scanning electron microscopy (SEM) on a JSM-6460 (Jeol, Japan) electron microscope with a resolution of $4 \mathrm{~nm}$ in the range of magnifications from $5 \times$ to $300,000 \times$. Similar reference experiments were carried out using the same plastics but without adding the catalyst (nichrome wire). Thus, two modes of plastics pyrolysis, thermal and catalytic, were realized.

The resulting SEM data are shown in (Figure 7). Since polyethylene does not contain any halogen atoms, initiation of metal dusting mechanism was not observed. The final material after the RAPET experiment at $800{ }^{\circ} \mathrm{C}$ is represented by initial piece of wire covered with spherical carbon deposits (Figure 7A). It should be noted that polyethylene undergoes pyrolysis at the same temperature without catalyst. In this case, the product is also spherical carbon of $1-2 \mu \mathrm{m}$ in size agglomerated into the secondary mesoporous particles (Figure 7B). Oppositely, polytetrafluorethylene contains a lot of fluorine but no hydrogen, which presence is also important for metal dusting by halogenated organics [64]. At the same time, as it is seen from (Figure 7C), the process of metal dusting takes place and leads to formation of a thick carbon covering around the nichrome wire. The obtained carbon deposits are represented mostly by twisted nanofibers.

Thermal pyrolysis of polytetrafluorethylene at $800{ }^{\circ} \mathrm{C}$ results in formation of two types of carbon deposits (Figure 7D): prolonged nanofibers and agglomerated nanospheres of about $100 \mathrm{~nm}$ in diameter. The most unique carbon nanostructures were observed after the catalytic pyrolysis of polyvinylchloride (Figure 7E). Note that this organic compound contains both hydrogen and halogen in its composition. The formed deposits are shaped as microcubes with pyramidal cavities. These cubes are 4-5 $\mu \mathrm{m}$ in size. According to data of local energy-dispersion X-ray microanalysis, they contain 70-85 at \% of carbon and 1530 at $\%$ of nickel with traces of chlorine. Non-catalytic thermal decomposition of PVC proceeds through trivial route leading to deposition of spherical carbon of $1-2 \mu \mathrm{m}$ in size, similarly as described above (Figure 7F). The resin wastes can also be decomposed using the RAPET approach. SEM images in Figures $7 \mathrm{G}$ and $7 \mathrm{H}$ demonstrate result of resin pyrolysis in the presence of nichrome wire at $800{ }^{\circ} \mathrm{C}$. It is seen that carbon deposits 
remind fibrous carbon. The thickness of the formed carbon layer is $15-20 \mu \mathrm{m}$. Close examination of the product (Figure 7D) has revealed that these fibers are comprised by carbon spheres of 1-2 $\mu \mathrm{m}$ in size.
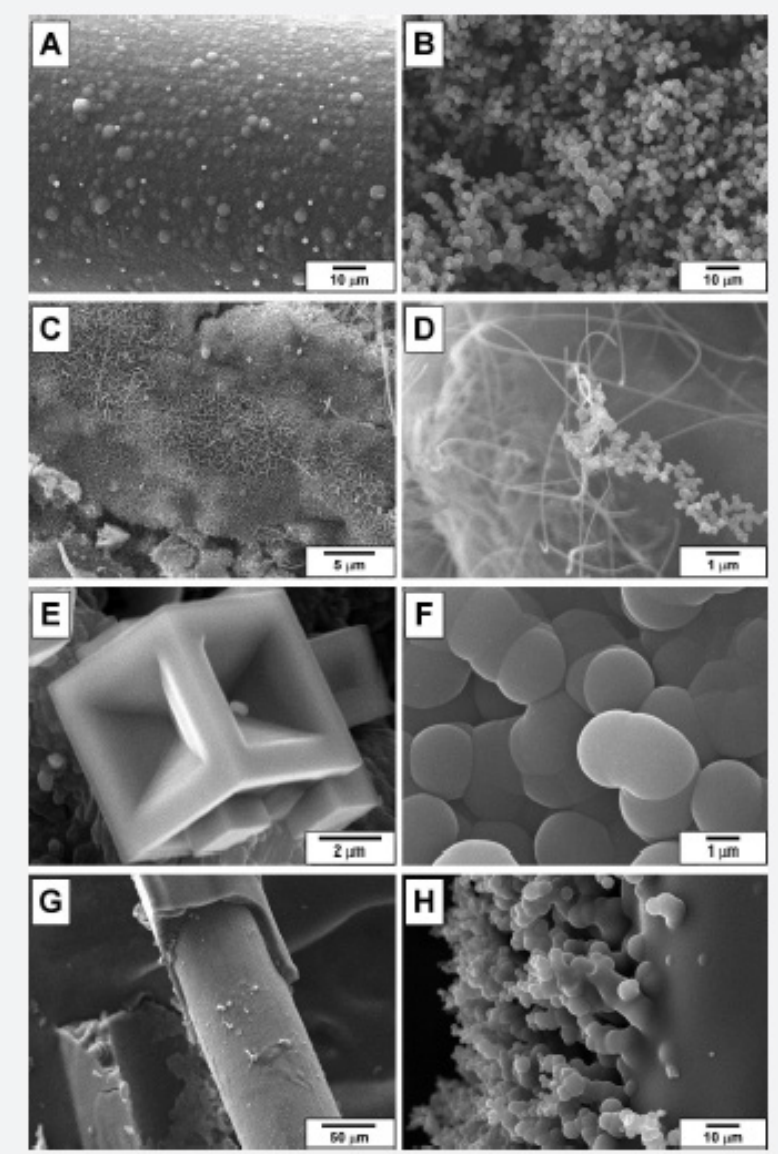

Figure 7: SEM images of the carbon product obtained after decomposition of polymers and resins in a closed reaction volume at $800{ }^{\circ} \mathrm{C}$ : A - polyethylene with $\mathrm{NiCr}$ wire; B - polyethylene without catalyst; $\mathrm{C}$ - polytetrafluoroethylene with $\mathrm{NiCr}$ wire; D - polytetrafluoroethylene without catalyst; E - polyvinylchloride with $\mathrm{NiCr}$ wire; $\mathrm{F}$ - polyvinylchloride without catalyst; $\mathrm{G}, \mathrm{H}-$ resins with $\mathrm{NiCr}$ wire.

\section{Conclusion}

The volume of global plastic production grows year by year with exponential rate. Low self-degradability of the plastic materials leads to accumulation of huge amount of solid plastic wastes, the most part of which is discarded. All these cause appearance of so-called plastic "mountains" and "oceans" having strong negative effect on the environmental, in general, and on human health, in particular. In the present study, application of the RAPET concept for recycling of the plastic wastes into valuable products (nanostructured carbon materials) was examined.

\section{Acnowledgement}

This study was funded by the Russian Foundation for Basic Research (project number 16-33-60034).

\section{References}

1. Patents for inventions (1857) UK Patent office, UK, pp. 255.

2. Industry Agenda (2016) The New Plastics Economy: Rethinking the future of plastics. World Economic Forum, p. 36.

3. Frolich PK (1940) Plastics and resins from hydrocarbons. Ind Eng Chem 32(3): 293-294.

4. Gnanou Y, Fontanille M (2007) Organic and physical chemistry of polymers. John Wiley Sons Inc, New Jersey, USA.

5. Fauvarque J (1996) The chlorine industry. Pure Appl Chem 68(9): $1713-1720$.

6. Ayres RU, Ayres LW (1996) The life cycle of chlorine: Part I II III IV Instead Fontainebleau France.

7. Lassen C, Sørensen G, Crookes M, Christensen F, Jeppesen CN, et al. (2014) Survey of short chain and medium chain chlorinated paraffins. The Danish Environmental Protection Agency Copenhagen Denmark.

8. Zapp JA (1962) Toxic and health effects of plastics and resins. Arch Environ Health An International Journal 4: 335-346.

9. Watson A, Brigden K, Shinn M, Cobbing M (2010) Toxic transformers; A review of the hazards of brominated chlorinated substances in electrical and electronic equipment. Greenpeace Research Laboratories Technical Note, USA.

10. Petrović EK, Hamer LK (2018) Improving the healthiness of sustainable construction: Example of polyvinyl chloride (PVC). Buildings 8(2): 28.

11. Hamilton JD, Reinert KH, Hagan JV, Lord WV (1995) Polymers as solid waste in municipal landfills. J Air Waste Manage 45: 247-251.

12. Jeffs M (1996) Polyurethane: a polymer addressing the environmental issues of the $21^{\text {st }}$ century. Cell Polym 15(2): 117-129.

13. Smits M (1996) The world of polymers and waste. In: Smits M (Ed.) Polymer Products and Waste Management p. 15-40.

14. Huang SJ (1995) Polymer waste management biodegradation incineration and recycling. J Macromol Sci A 32: 593-597.

15. Sperber RJ, Rosen SL (1974) Reuse of polymer waste. Polymer Plastics Technol Eng 3: 215-239.

16. Datta J, Kopczyńska P (2016) From polymer waste to potential main industrial products: Actual state of recycling and recovering. Crit Rev Environ Sci Technol 46: 905-946.

17. Harmon JP (1993) Combustion products from commercial polymers. Proceedings Annual Meeting Air Waste Management Association p. 12

18. Dawans F (1993) Treatment of polymer wastes. Caoutchoucs Plastiques 70: $43-50$

19. Dawans F (1992) Treatment of polymer wastes: chemical or energetic methods. Revue de 1 Institut Francais du Petrole 47: 837-867.

20. Koshti R, Mehta L, Samarth N (2018) Biological recycling of polyethylene terephthalate: a mini review. J Polym Environ 26(8): 3520-3529.

21. Kaminsky W (2010) Fluidized bed pyrolysis of waste polymer composites for oil and gas recovery. In: Goodship V (Ed.) Management Recycling and Reuse of Waste Composites pp. 192-213.

22. Mackey G (1991) A review of advanced recycling technology. ACS Symposium Series pp.161-169.

23. Curlee TR, Das S (1998) The viability of recycling plastics by tertiary processes. J Solid Waste Tech Manag 25: 148-160.

24. Shibuya H (1998) Pyrolysis technology for polymer wastes. Kobunshi 48: 778-781. 
25. Cao Y, Qiu Q Guo B, Jia D (2004) Recent development in recycling and reclamation of waste polymer. Gaofenzi Cailiao Kexue Yu Gongcheng 20: 33-36.

26. Hornung A, Seifert H (2006) Rotary kiln pyrolysis of polymers containing heteroatoms. In: Scheirs J Kaminsky W (Eds.) Feedstock Recycling and Pyrolysis of Waste Plastics pp. 549-567.

27. Vasile C, Brebu MA (2006) Thermal valorization of biomass and of synthetic polymer waste. Upgrading of Pyrolysis oils. Cell Chem Technol 40(7): 489-512.

28. Srinivasan A, Shanmugharaj AM, Bhowmick AK (2008) Waste rubber recycling. In: Bhowmick AK (Ed.) Current Topics in Elastomers Research pp. 1043-1066.

29. Hazrat MA, Rasul MG, Khan MMK, Azad AK, Bhuiya MMK, et al. (2014) Utilization of polymer wastes as transport fuel resources a recent development. Energy Procedia 61: 1681-1685.

30. Wong SL, Ngadi N, Abdullah TAT, Inuwa IM (2015) Current state and future prospects of plastic waste as source of fuel: A review. Renew Sustain Ener Rev 50: 1167-1180.

31. Zhang X, Lei H, Chen S, Wu J (2016) Catalytic co-pyrolysis of lignocellulosic biomass with polymers: a critical review. Green Chem 18: $4145-4169$

32. Ragaert K, Delva L, Van Geem K (2017) Mechanical and chemical recycling of solid plastic waste. Waste Manage 69: 24-58.

33. Guiney PD, Mclaughlin JE, Hamilton JD, Reinert KH (1997) Dispersion polymers. In: Hamilton JD Sutcliffe R (Eds.) Ecological Assessment of Polymers pp. 147-165.

34. Banerjee A, Chatterjee K, Madras G (2014) Enzymatic degradation of polymers: a brief review. Mater Sci Tech 30: 567-573.

35. Hoppe HG (1986) Degradations in seawater. Biotechnology 8: 453-474

36. Ali Shah A, Hasan F, Shah Z, Kanwal N, Zeb S, et al. (2013) Biodegradation of natural and synthetic rubbers: A review. Int Biodeter Biodegr 83: 145-157.

37. Li F (1988) Microbial degradation of synthetic polymers. Weishengwuxue Zazhi 8: 69-77.

38. Zheng Y, Yanful EK, Bassi AS (2005) A review of plastic waste biodegradation. Crit Rev Biotechnol 25(4): 243-250.

39. Andrady AL (1994) Assessment of environmental biodegradation of synthetic polymers. J Macromol Sci C 34: 25-76.

40. Kale G, Kijchavengkul T, Auras R, Rubino M, Selke SE, et al. (2007) Compostability of bioplastic packaging materials: an overview. Macromol Biosci 7(3): 255-277.

41. Franchetti SMM, Marconato JC (2006) Biodegradable polymers partial means to diminish the amount of plastic waste. Quimica Nova 29: 811816.

42. Hrdlovic P (1994) Degradable polymers: state of the art and future potentials. Plasty a Kaucuk 31: 202-209.

43. Das AK (2002) Degradable plastics. Popular Plastics Packaging 47: 8788.

44. Yang C, Peng T, Deng K, Zan L (2011) Solid phase photocatalytic degradation of waste plastics. Huaxue Jinzhan 23(5): 874-879.

45. Allen, Norman S (1996) Polymer photochemistry. Photochem 27: 303360.

46. Nikles DE, Farahat MS (2005) New motivation for the depolymerization products derived from poly (ethylene terephthalate) (PET) waste: a review. Macromol Mater Eng 290(1): 13-30.
47. Koo CM, Yu SW, Baek BK, Cho HK, Lee YW, et al, (2012) Recycling technology of crosslinked polymers using supercritical fluid. Elastomers and Composites 47: 111-120.

48. Kong L, Li G, He W, Wang H (2006) Development in disposal of organic wastes by supercritical and sub- critical hydrothermal treatment. Huagong Jinzhan 25: 469-474.

49. Arai K (1998) Conversion of polymers and biomass to chemical intermediates with supercritical water. Macromol Symp 135: 205-214.

50. Watt W (1969) Pyrolysis of Polyacrylonitrile. Nature 222: 265-266.

51. Yusof N, Ismail AF (2012) Post spinning and pyrolysis processes of polyacrylonitrile (PAN) based carbon fiber and activated carbon fiber: A review. J Anal Appl Pyrol 93: 1-13.

52. Pol VG, Pol SV, Gedanken A (2008) Semiconducting, magnetic or superconducting nanoparticles encapsulated in carbon shells by RAPET method. Carbon Sci Tech 1: 46-56.

53. Pol VG, Pol SV, Gedanken A (2009) One-step synthesis and characterization of $\mathrm{SiC} \mathrm{Mo} 2 \mathrm{C}$ and WC nanostructures. Eur J Inorg Chem 6: 709-715.

54. Pol VG, Pol SV, Gedanken A (2008) A precursor decomposition method for the fabrication of carbon related materials. In: Miyagawa H (Ed.) Recent Research Activities of Microand Nano Scale Carbon Related Materials pp. 163-194.

55. Pol VG, Pol SV, Gedanken A (2010) Properties of nanostructured metal oxides synthesized by RAPET approach. In: Umar A, Hahn YB (Eds.) Metal Oxide Nanostructures and Their Applications 1: 239-266.

56. Kenzhin RM, Bauman YI, Volodin AM, Mishakov IV, Vedyagin AA, et al. (2018) Synthesis of carbon nanofibers by catalytic CVD of chlorobenzene over bulk nickel alloy. Appl Surf Sci 427(1): 505-510.

57. Kenzhin RM, Bauman YI, Volodin AM, Mishakov IV, Vedyagin AA, et al. (2017) One step synthesis of nitrogen doped carbon nanofibers from melamine over nickel alloy in a closed system. Cheml Phys Lett 685: 259-262.

58. Kenzhin RM, Bauman YI, Volodin AM, Mishakov IV, Vedyagin AA, et al. (2018) Interaction of heteroatom containing organic compounds with bulk nickel alloy in a closed reactor system. JOJ Mater Sci 4: 555633.

59. Kenzhin RM, Bauman YI, Volodin AM, Mishakov IV, Vedyagin AA, et al. (2016) structural self organization of solid-state products during interaction of halogenated compounds with bulk Ni Cr alloy. Mat Lett 179: 30-33.

60. Kenzhin RM, Bauman YI, Volodin AM, Mishakov IV, Vedyagin AA, et al. (2017) Interaction of bulk nickel and nichrome with halogenated butanes. Reac Kinet Mech Catal 122: 1203-1212.

61. Grabke HJ (2003) Metal dusting. Mater Corros 54: 736-746.

62. Chun CM, Mumford JD, Ramanarayanan TA (2002) Mechanisms of metal dusting corrosion of iron. J Electrochem Soc 149(7): B348-B355.

63. Zhang J, Young DJ (2007) Kinetics and mechanisms of nickel metal dusting I. Kinetics and morphology. Corros Sci 49(3): 1496-1512.

64. Mishakov IV, Vedyagin AA, Bauman YI, Shubin YV, Buyanov RA, et al. (2018) Synthesis of carbon nanofibers via catalytic chemical vapor deposition of halogenated hydrocarbons. In: Lee C-S (Ed.) Carbon Nanofibers: Synthesis Applications and Performance Nova Science Publishers, New York, USA. 
This work is licensed under Creative Commons Attribution 4.0 License

DOI: 10.19080/JOJMS.2019.05.555660

\section{Your next submission with Juniper Publishers will reach you the below assets}

- Quality Editorial service

- Swift Peer Review

- Reprints availability

- E-prints Service

- Manuscript Podcast for convenient understanding

- Global attainment for your research

- Manuscript accessibility in different formats (Pdf, E-pub, Full Text, Audio)

- Unceasing customer service

Track the below URL for one-step submission https://juniperpublishers.com/online-submission.php 